\title{
Translating Scientific Terminology: Examples from the Arabic versions of Two International Magazines
}

\author{
Bahaa-eddin Hassan
}

\section{Doi:10.5901/mjss.2017.v8n2p183}

\begin{abstract}
The purpose of this study is to examine the strategies used in translating scientific terminology. It is an attempt to explore how scientific English terms are translated in the Arabic versions of two international magazines; namely, the famous Scientific American (Arabic Edition) and Nature (Arabic Edition). The evidence provided by these magazines is expected to explain to what extent semantic and communicative translation is crucial in rendering scientific terms into Arabic. It also classifies the different types of semantic translation.
\end{abstract}

Keywords: Scientific Translation, Terminology, Transliteration, Calque, Gloss Translation, Semantic and Communicative Translation, Globalization

\section{Introduction}

Scientific translation is an important channel of knowledge dissemination; i.e. it is a means of seeking knowledge to fulfill scientific research needs. Translation of English scientific texts into Arabic is extremely scarce and is not keeping pace with global knowledge explosion. Scientific translation is an important step to acquire new technologies. The system of terminology in scientific language is not closed and constant in the age of globalization. It is in constant development as the new scientific disciplines emerge and develop.

Terminology is one of the problems that translators face in translating scientific English texts into Arabic. A good scientific translator should guarantee an accurate rendering of terminology. Actually, Arabic suffers a serious shortage of scientific terminology. Language purists argue that translators should find original Arabic terminology which is better than loanwords. Selection of an equivalent scientific term in the target language also complies with the requirement of precise transmitting of thoughts and ideas. Therefore, terminology must be carefully chosen in order to be unequivocal.

Newmark $(1988 ; 1991)$ suggests that the issue is a conflict of loyalty to the source language or the target language. His semantic translation method attempts to be close to the phonetic, morphological and lexical structure of the source. It is similar to Eugene Nida's formal equivalence. His communicative translation method, also, attempts to produce a similar effect on the target language. It resembles Nida's dynamic equivalence.

\section{Significance and Scope of the Study}

The study focuses on the translation strategies of scientific terminology in Scientific American (Arabic Edition) and Nature (Arabic Edition) and the factors which play a role in the choice of these strategies. It does not deal with the other linguistic features of scientific and technical texts, or the stylistic genres on which they are based. It focuses on finding out the frequency of using transliteration, calque, gloss translation and communicative translation. It also provides a rationale beyond the frequent use of the frequently used strategy in translating the two magazines.

\section{Objectives of the Study}

The research problem for this study is to identify the frequency of using translation strategies in rendering English scientific terms into Arabic. The contribution of this study lies in its attempt to answer the following research questions:

1. How often are transliteration, calque, gloss translation and communication translation used in the translation of scientific terms?

2. What are the factors which play role in the choice of these strategies?

The study aims at setting criteria for the translation of scientific terms. 


\section{Literature Review}

There are many different translation strategies, most of which are based on equivalence. The concept of equivalence is a central and controversial issue in translation. It has been studied by various theorists (cf. Jakobson 1959, Catford 1965, House 1977, Nida and Taber 1982, Newmark 1988, Vinay and Darbelnet 1995 and Baker 1992). Since the introduction of semantic and communicative translation theories by Newmark (1988; 1991), there have been various studies on them. Some studies compare them; others analyze them in some specific literature texts or in the translation of news reports.

Scientific translation has been discussed by many scholars. Gerzymisch-Arbogast (1993) explains translation problems in technical and scientific translation. Gommlich (1993) utilizes text typology in scientific and technical translation. Franco Aixela (2004) surveys the history of technical and scientific translation. Few studies deal with how scientific terms are translated into Arabic. El-Shami (2010) discusses the translation of prefixes and suffixes in the scientific terms. El-Khoury (2010) examines the translation of medical terms into Arabic.

\section{Data Collection and Methodology}

Data in the study are scientific terms collected from the translated Arabic version of the famous Scientific American (Arabic Edition) and Nature (Arabic Edition). I depended on a descriptive analytic method: I have gone through the two magazines in the period from 1993 to 2016. Three hundred scientific terms have been chosen from each magazine. I selected scientific terms from miscellaneous fields, including astronomy, physics, computer studies, medicine ... etc. The criteria of choice are based on the following aspects:

1. Term recentness

2. Clarity of the term

To achieve a level of accuracy, a rich variety of techniques have been used, from manual search to dictionarybased methods. I collected manually the scientific terms. To restrict choices and identify the exact meanings of the English scientific terms I used Oxford Dictionary of Science to find out meanings. Then, I classified the terms into four categories:

1. Semantic translation at the phonetic level (transliteration)

2. Semantic translation based on morphological processes such as suffixation, derivation and reduplication (calque)

3. Semantic translation based on lexical equivalence (gloss translation)

4. Communicative Translation

A sample of data is provided in the appendix of the study for further investigation.

\section{Theoretical Framework}

\subsection{Nature of Scientific Texts}

Scientific texts have some distinctive characteristics. The use of terms, objectivity, and accuracy are the most important ones. Scientific texts have common features such as:

- Simple structure and sentence ordering

- Explicitness

- Objectiveness

- Impersonality

Lee-Jahnke (1998:83-84) shows how to render scientific and technical texts. First, translators should have scientific knowledge. The challenges for the scientific translator are to be able to research subjects and to have scientific knowledge in a particular field. Moreover, translation of science poses a huge linguistic challenge. The key feature of scientific texts is terminology which is considered a key principle in scientific knowledge. Terminology and science have been interwoven for a long period of time. The relation between terminology and science is even more strongly understood by seeing an intrinsic dependency of the development of language and the development of science. Gerhard and Wright (2001) designated a handbook to meet the practical needs of terminologists, translators and lexicographers. They argue that "the terminologist is usually focused on the designation of terms and has to consider various determining mechanisms such as affixation, prefixation, backformation, compounding, deprecation, borrowing and neologisation within specialist terms" (2001: 813). 


\subsection{Semantic Translation of Scientific Texts}

The paper draws on Peter Newmark's translation theory $(1988,1991)$. He distinguishes two kinds of translation; semantic translation and communicative translation. His semantic translation focuses on replicating the source text forms within the target language. It denotes formal correspondence between the source text (ST) and the target text (TT). It focuses on the phonetic, morphological and lexical structure of the text. Semantic translation is used in genres which are ST-biased. It is rendering of the contextual meaning of the ST according to the syntactic and semantic characteristics of the TT. It is similar to Nida's formal correspondence which focuses on form and content. It is author-centered, faithful, more literal and informative. Peter Newmark's semantic translation can be divided into three levels; phonetic level (transliteration), morphological level (calque) and lexical level (gloss translation).

\subsubsection{Semantic Translation at the Phonetic Level (Transliteration):}

Semantic translation at the phonetic level refers to transliteration which is a word taken from one language into another language alphabet. Transliteration is frequently used in scientific translation.. Familiar words are;
1. Alzheimer
الز هايمر
2. Microwave
3. SARS
ميكروويف
سارس

Transliteration follows the phonetic rules of the target language. Transliterated words are often naturalized to assimilate the structure of the target language. Translators introduce some phonetic and morphological changes to the foreign term (Ghazzala 1995). Naturalization of loanwords refers to the addition of some affixes to the foreign words without changing their roots. The affixes are added to suit the nature of the Arabic language:

Technology $\rightarrow$ تكنولوجيا

Technological $\rightarrow$ تكنولوجنى

Technologically $\rightarrow$ تكنولوجيا

Lasering $\rightarrow$ ليزرة

Ghazzala (1995) is in favor of using pure Arabic terms. For example, the word "تقنية" can be used to render the word "technology". According to Baker (1987) transcription and naturalization are rejected because they threaten the position of Arabic. In fact, these strategies do not explain the meaning of the words in Arabic. Notice, for example, how the following two words (ballistic and cruise) are transliterated:

Ballistic missile صواريخ باليستية

Cruise missile صو اريخ كروز

The Arabic reader may not know the meaning of "كروز" and "باليستية" Another example is the translation " الأمن "السيير انى "for the English phrase "cyber security". Using transliteration does not enrich Arabic vocabulary. In fact, it implies that Arab translators are not able to create new pure Arabic terms and prefer the easiest way to translate scientific terms.

\subsubsection{Semantic Translation at the Morphological Level (Calque):}

Calque or loan translation is a kind of semantic translation. This strategy renders a phrase borrowed from another language, keeping the source language structure.
لاهو ائى Anaerobic
(Scientific American 2015, Vol.7-8, p.74)
Gasohol بنزحول
(Scientific American 1994, Vol.12, p.58)
Some calque words are not natural. Consider the following words:
Spacetime مكان (Nature 2016, Vol.43, p.12)
Electromagnetic كهرطيسية (Scientific American 2000, Vol.14, no.3, p.48)

\subsubsection{Semantic Translation at the Lexical Level (Gloss Translation):}

Semantic translation at the gloss level refers to lexicalizing equivalent words in the target language. Translation as per the lexicon is much more preferable in some author-oriented scientific texts. Gloss translation aims at rendering the terms and concepts into the Arabic language by translating the lexicon. It receives much acceptance in some scientific texts. For example:

$$
\text { Resolution } \rightarrow \text { الميز } \quad \text { (Scientific American 2000, Vol.16, no.11, p.40) }
$$




$$
\begin{aligned}
& \text { Resolution } \rightarrow \text { الاستبانة } \quad \text { (Nature 2013, Vol.9, p.22) } \\
& \text { HDTV } \quad \rightarrow \quad \text { التليفزيون عالى الوضوح (Scientific American 2002, Vol.18, no.5-6, p.63) }
\end{aligned}
$$

\subsection{Communicative Translation of Scientific Texts}

On the contrary, communicative translation aims at influencing the reader. It is reader-centered and effect-oriented. Newmark proposes the principle of "equivalent effect". According to Newmark (1988), it focuses on making the target language readers understand the source language author's thoughts. It is used in genres which are communicative in nature such as news report, textbooks, and public announcement. The differences between communicative and semantic translation is based on their different emphasis. In semantic translation, the focus is on the original's formal properties. However, communicative translation does not adhere to the source language text. Then, it attempts to eliminate any exoticism and to look natural; smooth translation. While communicative translation attempts to produce on its readers an effect close to that of the original, semantic translation aims to render the semantic and syntactic structures of the original (Newmark 1991: 11).

Semantic translation [is] usually more awkward, more detailed, more concentrated, but briefer.... Communicative translation [is] easy reading, more natural, smoother, simpler, clearer, more direct, [and] more conventional... (1991: 11).

As pointed out by Newmark,

Communicative and semantic translation may well coincide... There is no one communicative or one semantic method of translating a text-these are in fact widely overlapping bands of methods. A translation can be more, or less, semantic-more, or less, communicative-even a particular section or sentence can be treated more communicatively or less semantically (1991: 10)

\section{Analysis}

This section deals with examples from the two English-Arabic translated scientific magazines. First, statistical data are offered to point out the frequency of the translation strategies used by the two magazines.

Table 1: Frequency and Percentage of Translation Strategy in Scientific American (Arabic Edition)

\begin{tabular}{|l|c|c|}
\hline Translation strategy & Frequency & Percentage \\
\hline Transliteration & 150 & $50 \%$ \\
\hline Calque & 23 & $7.6 \%$ \\
\hline Gloss Translation & 222 & $74 \%$ \\
\hline Communicative Translation & 24 & $8 \%$ \\
\hline
\end{tabular}

Table 2: Frequency and Percentage of Translation Strategy in Nature (Arabic Edition)

\begin{tabular}{|l|c|c|}
\hline Translation strategy & Frequency & Percentage \\
\hline Transliteration & 27 & $9 \%$ \\
\hline Calque & 2 & $0.6 \%$ \\
\hline Gloss Translation & 299 & $99.6 \%$ \\
\hline Communicative Translation & 6 & $2 \%$ \\
\hline
\end{tabular}

The first category of semantic translation, i.e. transliteration, has been frequently used in Scientific American (Arabic Edition). It has been used in almost $50 \%$ out of 300 terms. Examples of transliterated words are:

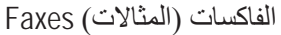
(Scientific American 1996, Vol.12, no.7-8, p.40)
Profile بروفايل (سيماء / لاحثة)
(Scientific American 2011, Vol.27, no.9-10, p.50)

Some transliterated words are naturalized by using derivational processes.

Automata أتوماتا (أتمنة / أتوماتيكية) (Scientific American 2015, Vol.8, no.3-4, p.26)

كيموكينة

Chlorinated مكلورة 
غلفنة Galvanization

تغويز Gasification

فلترة فائقة

تحليق مؤتمت Automated flight
(Scientific American 1997, no.1, p.52)

(Scientific American 1993, no.7-8, p.26)

(Scientific American 1999, no.8-9, p.95)

(Scientific American 2015, no.11-12, p.28)

It is noticed that while Nature (Arabic Edition) utilizes gloss translation, Scientific American (Arabic Edition) uses transliteration. The following two terms are transliterated in Scientific American (Arabic Edition);
DNA الدنا
(Scientific American 1995, no.1, p.70)
RNA الرنانا
(Scientific American 2014, no.9-10, p.18)

However, it is lexically translated in Nature as;

DNA الحمض النووى (Nature 2013, Vol.2, p.13)

RNA الحمض النووى الريبى (الريبوزى) (Nature 2013, Vol.2, p.13)

Some terms are translated through a combination of two or three strategies, as the case in Scientific American (Arabic Edition). Translation of scientific terms in American Scientific (Arabic Edition) can be divided into three kindssemantic translation, communicative translation and the combination of semantic and communicative translation. It has been noticed that the rate of using loan words in Arabic scientific texts is higher than the rate of coining new Arabic words in Scientific American (Arabic Edition). However, Nature (Arabic Edition) adopts the principle of gloss translation.

In other cases, Scientific American (Arabic Edition) combines transliteration and gloss translation;

Pixel

(Scientific American 1995, no.7-8, p.65)

بقعة ضوء (1) بكل (1)

neuron

(Scientific American 2015, no.7-8, p.23)

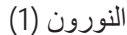

العصبون (2) (1) (1) (2)

quantum

كو انتى (1)

(Scientific American 2015, no.9-10, p.4)

كمومى (2)

Again, in the previous examples, the second translation may be easy to the general reader.

The second category of semantic translation or calque is also frequent in Scientific American (Arabic Edition). 23 terms out of 300 terms have been translated by calque. Examples are;

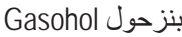

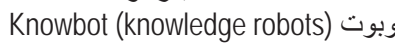
(Scientific American 1994, no.12, p.58)
Nanobot الإنسالية (إنسان + آلى آلى)

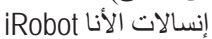

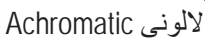
Interneurons مابين العصبونات
Botnet (robot network) البونت
(Scientific American 1996, no.7-8, p.30)
(Scientific American 2015, no.11-12, p.20)
(Scientific American 2013, no.29, p.53)
(Scientific American 2002, no.5-6, p.43)
(Scientific American 2015, no.7-8, p.23)
(Scientific American 2012, no.3-4, p.90)

اللاهو ائى Anaerobic

Calque is used as strategy but it should be on condition that it is intelligible. The following words are translated as calque but in an awkward way:
الكهرطيسية Electromagnetic
(Scientific American 2015, no.5-6, p.26)
Spacetime زمكان
(Scientific American 2015, no.9-10, p.34)
البيوزمنية Chronobiological
فوبشرية Superhuman
(Scientific American 2015, no.7-8, p.45)
مافوسجى Ultraviolet
(Scientific American 2015, no.5-6, p.63)
وعاؤوم Hemangioma
(Scientific American 1996, no.11-12, p.13)
Submarine تحبحرى
(Scientific American 1998, no.1-2, p.97)
حيوم Biome

\author{
(Scientific American 1998, no.4, p.26) \\ (Scientific American 1990, no.1, p.99)
}

They can be best translated as follows:

Electromagnetic الكهرومغناطيسية

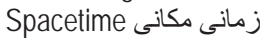

علم البيولوجيا الزمنى زمانى

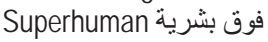

مافوق بنفسجى Ultraviolet 


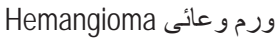

تحت بحرى Submarine

جينو مجمو عة كائنات حية Biome

The third category of semantic translation; i.e. translation at the lexical level, is also frequent in the two magazines. 299 terms out of 300 terms have been translated lexically in Nature.

On-line معلومات مبانشرة فورية

Placebo دواء غفل (أدوية و همية)

(Scientific American 2009, no.5-6, p.25)

Genome المادة الور اثثية (الجينوم) (درية)

آلة جزيئية Nanomachine

(Scientific American 2015, no.11-12, p.56)

(Scientific American 2015, no.11-12, p.34)

(Nature 2013, Vol.2, p.14)

Epigenetic marks علامات ور اثية غير جينية (Nature 2014, Vol.6, p.20)

Generic medicines أدوية جنيسة جنية

(Nature 2014, Vol.6, p.19)

Gonotrophic dissociation التغذية التو الدية العرضية (Nature 2015, Vol.2, p.18)

Diffraction pattern أنماط حيود

(Nature 2016, Vol.4, p.22)

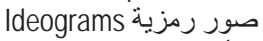

(Nature 2015, Vol.2, p.30)

Heartbleed ثغرة أمنية (خطأ برمجى) (Scientific American 2015, no.7-8, p.50)

It is also noticed that some scientific terms undergo a process of extraction. For example 'cloud system' is used instead of 'cloud computing system'. Good scientific translation lexicalizes the extracted term, for example;

نظام السحابة الحاسوبية Cloud system (Nature 2014, Vol.7, p.26)

Valence band نظام التكافؤ الكيميائىبانية (Nature 2012, Vol.12, p.71)

Communicative translation, on the other hand, is a challenge for the scientific translator. It requires efforts to paraphrase and explain a term. Notice how the following word "spam" is translated:

Spam

(Scientific American 2015, no.7-8, p.50)

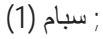

البريد الإلكترونى المز عج المرسل بكميات كبيرة إلى المتلقين دون رضاهم (2)

The two translations both have the same meaning. The first translation is semantic and the second translation is communicative. The study also finds out that communicative translation is more used in Scientific American (Arabic Edition) with a percentage of $8 \%$ (24 terms). Nature (Arabic Edition) utilizes this strategy in only 6 terms. Examples are;

Esperanto

الإسبر انتية (1)

لغة دولية مبسطة للتفاهم (2)

Quarks

(Scientific American 2015, no.5-6, p.27)

الكو اركات (1)

جسيمات تكون عالمنا (2) (1) (1)

Glue

(Scientific American 2015, no.7-8, p.42)

(1) الكليونات

جسيمات صغيرة (2)

Silcene

(Scientific American 1996, no.7-8, p.25)

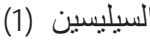

رقائق سيليكون تشبه الجر افين بسمك ذرة واحدة (2)

Nevertheless, semantic translation and communicative translation are not in complementary distribution as there are some overlaps between them as well. The following are examples of communicative translation in Scientific American (Arabic Edition).

Table 3: Examples of Communicative Translation

\begin{tabular}{|c|c|}
\hline Term & Communicative Translation \\
\hline $\begin{array}{l}\text { Spintronics } \\
\text { (Scientific American 2014, no.5-6, p.77) }\end{array}$ & 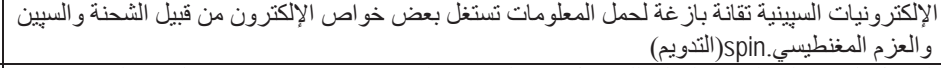 \\
\hline $\begin{array}{l}\text { WiMAX } \\
\text { (Scientific American 2007, no.11-12, p.42) }\end{array}$ & 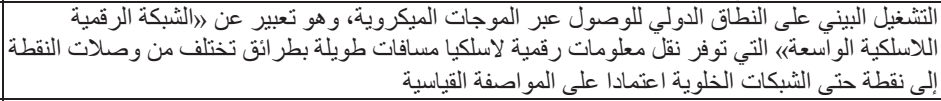 \\
\hline $\begin{array}{l}\text { field-effect t } \\
\text { (Scientific A }\end{array}$ & تر انزستور يمر معظم تياره عبر قناة يمكن التحكم في مقاومتها بو اسطة حقل كهربائي مستعرض متغير. \\
\hline $\begin{array}{l}\text { quantum dot } \\
\text { (Scientific American 2010, no.3-4 }\end{array}$ & 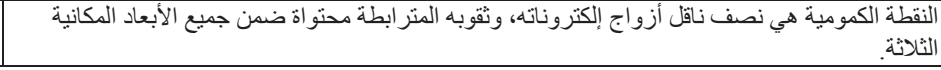 \\
\hline
\end{tabular}


Of course, communicative translation is not meant to be better than semantic translation. The choice of translation strategy depends on specific conditions: the communicative situation. One finding of the study is that choice of translation strategy depends on the communicative value of the text. It plays a role in determining the translation strategy used; i.e. text type, readership, the roles of translators, and functions of the texts. It imposes certain limits on the translator's freedom of choice. It subsumes the following:

1. Who is the intended audience?

2. What is the text type?

3. What is the function of the text?

With regard to readership, if priority is given to audience, communicative translation is used; if priority is given to author, semantic translation is used. The function of the text is also important. Scientific texts have informative function. The study stresses that the communicative value of the text is important to determine the translation strategy. As for text type, Newmark (1988:40) proposes three text types: namely, expressive texts, informative texts and vocative texts. According to Newmark, communicative translation is preferred in scientific texts because they are informative (cf. Newmark 1988, 1991). He views communicative translation as smother and simply clearer, while semantic translation is viewed as awkward, more detailed and more concentrated.

It has been noticed that many English scientific terms have become loan words in Arabic under the umbrella of borrowing. The present situation can be justified by two reasons:

1- The huge flux of information in the age of globalization helps transfer of terminology. Cronin (2003) explains that translators, like everybody else, are susceptible to the influence of globalization. Since globalization cancelled space, it seems to be synonymous with instantaneous communication. This impact is especially on non-literary texts or scientific texts. Globalization has imposed the rapid flow of scientific and technological terms. This situation has been encountered by a blurred vision in Arabic scientific translation: there is no unified strategy in translating scientific terms and excessive dependence on transliteration or lexical borrowing. In the global age the Arab world is not scientifically and technologically advanced. Therefore, the developed countries are scientifically dominant and their global language, English, is also dominant. Transliteration or lexical borrowing in the age of globalization is one-way process which takes place from the culturally-dominant language to the borrowing languages. Cronin also raises the issue of why nations need translation. He points to the danger of 'foreignizing' translation strategy advocated by those like Schleiermacher. The situation is beneficial for the global language which retains most of the scientific terms. He recommends facing the challenge of foreign terms in translation and inventing equivalent terms in national languages to expand its lexical base.

2- Transliteration is easier than gloss translation or communicative translation.

It is quite clear in the analysis that the strategies used in translating scientific terms have more than one option. The main finding of the study is that semantic translation is more used in the two magazines. While Nature (Arabic Edition) opts for gloss translation, Scientific American (Arabic Edition) favors a combination of semantic and communicative translation.

\section{Conclusion}

The study surveys the two kinds of translation proposed by Peter Newmark; i.e. semantic and communicative translation and their use in the translation of scientific texts. It concludes that Scientific American (Arabic Edition) uses semantic translation, communicative translation and a combination of the two methods. However, Nature (Arabic Edition) depends heavily on gloss translation. The study is in favor of using gloss translation to enrich Arabic repertoire and using communicative translation in case the scientific term needs clarification.

The study argues for the option of gloss translation that typifies semantic equivalence or formal equivalence, where form and content are reproduced as faithfully as possible to address the specialized reader. In fact, as prescribed by Newmark, communicative translation is suitable for scientific texts. The study is in favor of using both strategies to address both the general and specialized reader. This solution has been adopted by Scientific American (Arabic Edition).

\section{References}

Baker, Mona. 1992. In Other Words: a Coursebook on Translation, Routledge, London

Baker, Mona. 1987. "Review of methods used for coining new terms in Arabic". Meta: Journal des Tracducteurs/ Meta Translators' Journal. Vol.32, 186-188. Online: http://www.erudit.org/documentation/eruditPolitiqueUtilisation 
Catford, John C. 1965. A Linguistic Theory of Translation: an Essay on Applied Linguistics. London: Oxford University Press

Cronin, Michael. 2003. Translation and Globalization, London and New York: Routledge

Franco Aixela, J. 2004. "The Study of Technical and Scientific Translation: An Examination of its Historical Development", Journal of Specialised Translation, Issue 1, pp. 29-49

Gerhard, Budin and Wright, Sue Ellen. 2001. Handbook of Terminology Management. Amesterdam/Philadelphia: John Benjamins.

Gerzymisch-Arbogast, H. 1993. "Contrastive Scientific and Technical Register as a Translation Problem in Scientific \& Technical Translation". In: S.E. Wright (ed) Scientific and Technical Translation: American Translators' Association Scholarly Monograph Series, Vol. VI 1993. Amsterdam, The Netherlands and Philadelphia, USA: John Benjamins

Ghazala, Hasan. 1995. Translation as problems and solutions: A course-book for university students and trainee translators. Valetta Malta: Elga Publication.

Gommlich, Klaus. 1993. "Text typology and translation-oriented text analysis". In: S.E. Wright (ed) Scientific and Technical Translation: American Translators' Association Scholarly Monograph Series, Vol. VI 1993. Amsterdam, The Netherlands and Philadelphia, USA: John Benjamins

House, Juliane. 1977. A Model for Translation Quality Assessment. Gunter Narr, Tübingen

Jakobson, Roman. 1959. "On linguistic aspects of translation". In R.A. Brower (Ed.), On Translation, Harvard University Press, Cambridge, MA, pp. 232-239

El-Khoury, Tatania. 2010. "On Nominal Reduction or Expansion Solutions: A study in Medical Terminology", Al-Arabiyya wal-tarjamah, Vol. 2, 2010. Arab Organization for Translation Journal.

Lee-Jahnke, H. 1998. "Training in Medical Translation with Emhpasis on German". In: F. Massardier-Kenney and H. Fishbach (eds.) Translation and Medicine, American Translators Association Series, Vol. X, pp. 1-12

Nida, Eugene A. and Taber, C.R.. 1982. The Theory and Practice of Translation. E. J. Brill, Leiden (1969/1982)

Newmark, Peter. 1991. About Translation: Multilingual Matter. Clevedon, Philadelphia, Adelaide: Multilingual Matters Ltd.

Newmark, Peter. 1988. Peter Newmark. A Textbook of Translation. Prentice Hall, London

El-Shami, Tayssir. 2010. "Scientific Translation between the author and the reader", Al-Arabiyya wal-tarjamah, Vol. 3, 2010. Arab Organization for Translation Journal

Vinay, J.P. and Darbelnet, J. 1995. Comparative Stylistics of French and English: a Methodology for Translation. (J.C. Sager, M.J. Hamel, Trans.) John Benjamins, Amsterdam /Philadelphia

\section{Appendices: Sample of Data}

\section{Appendix I: Scientific American (Arabic Edition)}

\begin{tabular}{|c|c|c|}
\hline English Term & Arabic Translation & Type of translation \\
\hline Bytes & بيتات & Transliteration \\
\hline Byte $=8$ bits & بايت & Transliteration \\
\hline Bit & بتة & Transliteration \\
\hline Bits & 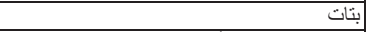 & Transliteration \\
\hline serendipity & سرنديبية [اكتشاف أشياء مهمة مصادفة] & Transliteration \& Communicative Translation \\
\hline resolution & الميز & Gloss Translation \\
\hline High resolution & عالبة الميز & Gloss Translation \\
\hline On-line & معلو مات مباشرة فورية & Communicative Translation \\
\hline prodigy & برودجى & Transliteration \\
\hline Esperanto & |الإسبر انتية & Transliteration \& Communicative Translation \\
\hline Knowbot = knowledge robots & النوبوت & Transliteration \\
\hline HDTV & التليفزيون العالى الوضوح & Gloss Translation \\
\hline x-ray & أشعة سينية & Gloss Translation \\
\hline Soliton & سوليتون (موجة وحيدة) & Transliteration \& Communicative Translation \\
\hline Video teleconferencing & التداول الفيديوى عن بعد & Gloss Translation \\
\hline Encoding & تكويد (تورية) & Transliteration \& Gloss Translation \\
\hline Decoding & كسر التكويد & Transliteration \& Gloss Translation \\
\hline microwave & الموجات المكروية (الصغرية) & Gloss Translation \\
\hline Faxes & الفاكسات (المثالات) & Transliteration \& Gloss Translation \\
\hline Nucleus accumbens & نواة منكئة & Gloss Translation \\
\hline acetylation & أستلة & Transliteration \\
\hline achromatic & لالونى لونى & Calque \\
\hline Nanobots & الإنسالات النانوية- جمع إنسالة نحت من إنسان آلى & Calque \& communicative Translation \\
\hline DNA & الدنا & Transliteration \\
\hline Nanoparticle & جسيم نانوى & Transliteration \& Gloss Translation \\
\hline Drugs in disguise & أدوية ممو هة & Gloss Translation \\
\hline Metastases & ورم حبيث- سرطان منقدم & Gloss Translation \\
\hline Nanodrug & |أدوية نانوية & Transliteration \& Gloss Translation \\
\hline Sheath material & مادة الغمد & Gloss Translation \\
\hline Computer chips & | شيبات حاسو بية & Transliteration \& Gloss Translation \\
\hline
\end{tabular}




\begin{tabular}{|c|c|c|}
\hline English Term & Arabic Translation & Type of translation \\
\hline Automated flight & |تحليق مؤتمت & Calque \& Gloss Translation \\
\hline Genome & | الجينوم (المادة الور اثية) & Transliteration \& Gloss Translation \\
\hline Quarks & $\begin{aligned} \\
\end{aligned}$ & Transliteration \& Communicative Translation \\
\hline Quantum & كمومى & Gloss Translation \\
\hline Hard drive & سو اقة & Gloss Translation \\
\hline Entropy & | ل الإنتروبية & Transliteration \\
\hline Thermodynamic & |ترموديناميك & Transliteration \\
\hline \begin{tabular}{|l|} 
Neuron \\
\end{tabular} & |النورون (العصبون) & Transliteration \& Gloss Translation \\
\hline Neurobiology & عصبيولوجى & Transliteration \& Gloss Translation \\
\hline Plate tectonics & ال الو اح تكتونية & Gloss Translation \\
\hline Space-time & |زمكان & Calque \\
\hline Iphone 6 & | الهاتف الذكى & Gloss Translation \\
\hline Memristor =memory + resistor & مقاوم الذاكرة & Gloss Translation \\
\hline Cache memory & |ذاكرة خبيئة & Gloss Translation \\
\hline Flash memory & | ذاكرة ومضية & Gloss Translation \\
\hline Photonics & |الفوتونيات & Transliteration \\
\hline Housefly & |فر اشة منزلية & Gloss Translation \\
\hline Video monitor & مظهار فيديوى & Transliteration \& Gloss Translation \\
\hline Routers & موز عات & Gloss Translation \\
\hline Chromosome & الكروموسوم (الصبغى) & Transliteration \& Gloss Translation \\
\hline Monoclonal & وحيد النسيلة & Gloss Translation \\
\hline Placebo & ل دواء غفل (أدوية و همية) & Gloss Translation \\
\hline Hard wiring & البنية الور اثية & Gloss Translation \\
\hline interneurons & مابين العصبونات & Calque \\
\hline Glue & الكسيونات صغيرة و هى منحوثة عن أصلها الانجليزى) & Transliteration \& Communicative Translation \\
\hline Photon & الفوتون & Transliteration \\
\hline Femtoscope & 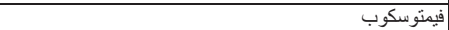 & Transliteration \\
\hline Metabolism & الإستقلاب (الأيض) & Gloss Translation \\
\hline chronobiological & | البيوزمنية & Calque \\
\hline Botnet $=$ robot network & ش ت مبكة البوتتت & Transliteration \\
\hline Spam & رسائل مز عجة (سبام) & Transliteration \& Gloss Translation \\
\hline GPS satellites & منظومة (نظام) تحديد المواقع العالمية & Gloss Translation \\
\hline Internet of things & أجهزة انترنت الأشياء & Gloss Translation \\
\hline Heart bleed & لئغرة أمنية (خطأ برمجي) (حاسوب) & Gloss Translation \\
\hline SSL & مآخذ التوصيل الآمنة & Gloss Translation \\
\hline Open SSL & برمجيات التشفير & Gloss Translation \\
\hline Vulnerabilities & اثغرات أمنية & Gloss Translation \\
\hline RNA & الرنا & Transliteration \\
\hline Nucleotides & نو كليو تيدات & Transliteration \\
\hline Cable network & الشبكة كبلية & Transliteration \& Gloss Translation \\
\hline Camcorder & جهاز آلذة التصوير و التُسجيل & Gloss Translation \\
\hline Camless & | عديم الكامة & Calque \\
\hline Cathode & كاثود (مهبط) & Transliteration \& Gloss Translation \\
\hline CD-ROM & سى دى روم (قرص مدمج) & Transliteration \& Gloss Translation \\
\hline Cellular automata & أتو ماتا (أتمتنة / أتو ماتيكية) خلوية & Transliteration \& Gloss Translation \\
\hline Chemokine & منشط كيميائي (كيمو كينة) & Transliteration \& Gloss Translation \\
\hline Chlorinated & 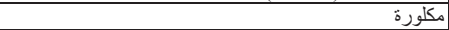 & Transliteration \\
\hline Clone & 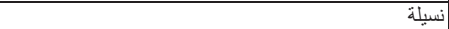 & Gloss Translation \\
\hline Cloning & استنساخ (استنسال) (كلونة) & Transliteration \& Gloss Translation \\
\hline Dialysis & ديلزة (تحال) & Transliteration \& Gloss Translation \\
\hline DVD & شاشة عرض فيديوية رقمية (دى فى دى) & Transliteration \& Gloss Translation \\
\hline Disk drive & سو اقة (مسير ) القرص & Gloss Translation \\
\hline Biome & حيوم & Gloss Translation \\
\hline Dialysis & ديْلزة (تحال) & Transliteration \& Gloss Translation \\
\hline Diode & ل ديود (صمام ثنائي) & Transliteration \& Gloss Translation \\
\hline facsimile (fax)o & فاكس (مثالة) & Transliteration \& Gloss Translation \\
\hline iROBOT & إنسالات الأنا & Calque \\
\hline Robotics & إنسالية & Calque \\
\hline connectomics & كو نيكتو ميكس & Transliteration \\
\hline Human Connectome Project & مشروع الكونيكتوم البشري & Transliteration \& Gloss Translation \\
\hline Pixel & بقعة ضوء (بيكسل) & Transliteration \& Gloss Translation \\
\hline anyons & الأنيونات & Transliteration \\
\hline Qubits & ككيوبتات & Transliteration \\
\hline Profile & بروفيل تعريب لِ : أو سيماء، أو لاحة & Transliteration \& Gloss Translation \\
\hline https & الإيروتوكول & Gloss Translation \\
\hline spintronics & 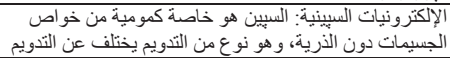 & Transliteration \& Communicative Tra \\
\hline
\end{tabular}




\begin{tabular}{|c|c|c|}
\hline English Term & Arabic Translation & Type of translation \\
\hline & 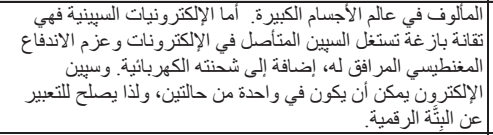 & \\
\hline HDD & |قرص صلب بخزن 16.5 جيكًابايت في خمسة أطباق قطر كل منها & Communicative Translation \\
\hline CD DVD & الأقر اص المثر اصة وأقر اص الفيديو الرقمي & Gloss Translation \\
\hline Wifi & 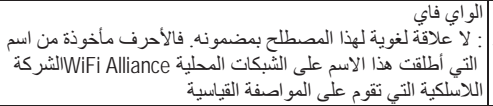 & Transliteration \& Communicative Translation \\
\hline broadband service & خدمات عريضة النطاق & Gloss Translation \\
\hline WIMAX & 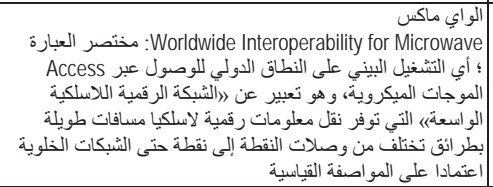 & Transliteration \& Communicative Translation \\
\hline Grid & network. تُرجمت إلى (اشبيكة") بسبب استخدام (ضشبكة)ر مقابل & Gloss Translation \\
\hline residual photons & |الفوتونات المتبقية & Transliteration \& Gloss Translation \\
\hline Spam & 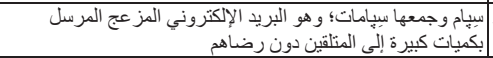 & Transliteration \& Communicative Translation \\
\hline ribosome & 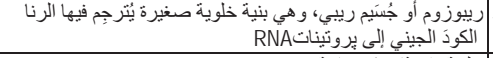 & Transliteration \& Communicative Translation \\
\hline galvanization & |غلفنة (استثارة كهربائية) & Transliteration \& Gloss Translation \\
\hline gas chromatography & | استشر اب غازي (فصل لوني بالغاز) & Gloss Translation \\
\hline gas-filter radiometry & |قياس الإشعاع بمرشح غاز & Gloss Translation \\
\hline gasification & اتغويز (تحويل مادة إلى غاز) & Gloss Translation \\
\hline Gasifier & مغوز & Gloss Translation \\
\hline Gasohol & | بنزحول & Calque \\
\hline quantum bit (qubit) & البتة كمومية (كوبتة) & Transliteration \& Gloss Translation \\
\hline quantum chromodynamics (QCD) & | ديناميكا لونية (كروموديناميك/تحريك لوني) كمومية & Transliteration \& Gloss Translation \\
\hline quantum computing & |حوسبة كمومية (كو انتية) & Transliteration \& Gloss Translation \\
\hline quantum electrodynamics & | إلكتروديناميك (كهرديناميكي/كهردينامي) كمومي & Transliteration \& Gloss Translation \\
\hline Quarry & (كو اري (طريدة' & Transliteration \& Gloss Translation \\
\hline Quasar & | كوازار (شبه نجم) & Transliteration \& Gloss Translation \\
\hline radio carrier wave & | موجة حاملة راديوية & Transliteration \& Gloss Translation \\
\hline ultrasonic & |فوق صوتي (فوصوتي) & Gloss Translation \\
\hline ultraviolet B radiation & |إنشعاع بائي ما فوق بنفسجي (مافوسجي) & Gloss Translation \& calque \\
\hline $\begin{array}{l}\text { Handheld Device Markup Language } \\
\text { (HDML) }\end{array}$ & |لغة تأثير للأجهزة المحمولة باليد & Gloss Translation \\
\hline hard X-ray & |أشعة سبنية نفاذة (حادة/قاسبة) & Gloss Translation \\
\hline hardware & عتاد (عتاديات/معدات/مكو نات مادية/تجهيز ات) صلب & Gloss Translation \\
\hline Hemangioma & و عاؤوم (ورم وعائي) & Calque \\
\hline high-definition television (HDTV) & التلفزيون عالي الوضوح & Gloss Translation \\
\hline immediate early gene & |جينة مبكرة فورية & Gloss Translation \\
\hline Kinin & كينين (قينين) & Transliteration \\
\hline Laptop & |حاسوب حمول (حضني/محمول/حجري/نقال) & Gloss Translation \\
\hline laptop device & |أداة حضنية (حجرية) & Gloss Translation \\
\hline laser diode & | ثنائي (ديود/صمام ثنائي) ليزري & Transliteration \& Gloss Translation \\
\hline laser fluorescence microscope & |مجهر تفلور ليزري & Transliteration \& Gloss Translation \\
\hline laser force microscope (LFM) & |مجهر القوة الليزرية & Transliteration \& Gloss Translation \\
\hline laser-projection system & | منظومة الإسقاط الليزري & Transliteration \& Gloss Translation \\
\hline Lasing & |ليزرة (ملازرة) & Transliteration \& Gloss Translation \\
\hline light emitting diode (LED) & |ديود إشعاع (باعث/مصدر) ضوئي & Transliteration \& Gloss Translation \\
\hline Tab & بطاقة (حاسو بيية) & Gloss Translation \\
\hline Tablet & ألويح حاسوبي (رقمي) & Gloss Translation \\
\hline circuits and electronics & | ل دارات و إلكترونيات & Gloss Translation \\
\hline Universal Serial Bus (USB) & |وصلة تسلسلية عالمية (مسرى تسلسلي شامل) (عميم) & Gloss Translation \\
\hline $\begin{array}{l}\text { Ultra Violet Coronagraph Spectrometer } \\
\text { (UVCS) }\end{array}$ & | مطياف راسم الإكليل لفوق البنفسجية & Gloss Translation \\
\hline Ultrafiltrating & |فلترة (تصفية) فائقة & Transliteration \& Gloss Translation \\
\hline Ultraviolet & |فوق بنفسجي (فوسجي) & Calque \& Gloss Translation \\
\hline vision chip & |شيبة الرؤية & Transliteration \& Gloss Translation \\
\hline Microcell & | خلية ميكروية & Transliteration \& Gloss Translation \\
\hline Microchimerism & | كيمرة (خيمزة) ميكروية & Transliteration \& Gloss Translation \\
\hline
\end{tabular}




\section{Appendix II: Nature (Arabic Edition)}

\begin{tabular}{|c|c|c|}
\hline English Term & Arabic Translation & Type of translation \\
\hline Photoelectro chemical energy & الكيمباء الكهروضوئية & Calque and Gloss Translation \\
\hline Autostereoscopic multiview 3D display & آلّة العرض ثلاثية الأبعاد متعدُّدة المناظر ذات التجسيم الآلي & Gloss Translation \\
\hline Nanomachine /molecular machine & آللة جزيئية & Gloss Translation \\
\hline Clinical research & أبحاث إكلينيكية & Transliteration \& Gloss Translation \\
\hline Generic medicines & ) أدوية جنيسة (غير محدودة الملكيّة & Gloss Translation \\
\hline Hyperbolic metasurfaces & أسطح القُطع الز ائد الفائقة & Gloss Translation \\
\hline Nanowires & أسلاك نانوية & Transliteration \& Gloss Translation \\
\hline Hominin & أشباه البشر & Gloss Translation \\
\hline Cosmic Microwave Background (CMB) & أشُعة الخلفيَّة الكونيّة & Gloss Translation \\
\hline Fibromyalgia & ألم عضلي ليفي & Gloss Translation \\
\hline Ischaemic heart disease & أمر اض نقص تروية القلب & Gloss Translation \\
\hline Photomultiplier tube & أنبوب تضخيم ضوئي & Gloss Translation \\
\hline Anthropogenic activities & أنشطة بشرية & Gloss Translation \\
\hline Diffraction patterns & أنماط حيود & Gloss Translation \\
\hline Karyotypes & 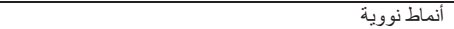 & Transliteration \& Gloss Translation \\
\hline Limnetic species & أنو اع سطية التغذية & Gloss Translation \\
\hline Subtype-selective & ل) أنواع فر عبة انتقائية، نمُبْطُ انتقائي (في تصنيف الأحياء & Gloss Translation \\
\hline Benthic species & 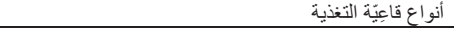 & Gloss Translation \\
\hline Zinc-finger nuclease & إنزيم نيو كلييز إصبع الزنك & Gloss Translation \\
\hline Ideograms & إيديوجر امات/ صور رمزية & Transliteration \& Gloss Translation \\
\hline CITES & 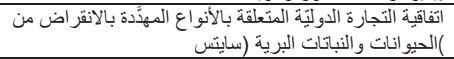 & Transliteration \& Gloss Translation \\
\hline Graviational Microlensing & 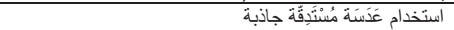 & Gloss Translation \\
\hline Chelation & استخلاب & Gloss Translation \\
\hline Rotoscoping & استنساخ المشهذ الحقيقي & Gloss Translation \\
\hline Autism spectrum disorder & اضطر اب طيف الثوحد & Gloss Translation \\
\hline Metabolic derangement & اضطر ابات أيضية & Gloss Translation \\
\hline Anaglyph 3D & الأسلوب التجسيمي & Gloss Translation \\
\hline Ultra Luminous X-rays & الأشعة السينية فائقة التألق & Gloss Translation \\
\hline Metabolic diseases & الأمر اض الأبضية & Gloss Translation \\
\hline Metabolic diseases & الأمر اض الأيضية & Gloss Translation \\
\hline Biosecurity & الأمن الحيوي & Gloss Translation \\
\hline Carbon nanotubes & الأنابيب النانوية الكربونية & Transliteration \& Gloss Translation \\
\hline Adaptive radiation & الإشعاع النُّكُفِفي & Gloss Translation \\
\hline Sonoluminescence & الإشعاع الضوئي الصوتي & Gloss Translation \\
\hline Spintronics & الإلكترونيات المغزلية & Gloss Translation \\
\hline RNA exonuclease enzymes & الإنزيمات المحفُّة للانفلاق الطرفي للحمض النووب الريبوزي & Gloss Translation \\
\hline Stick-slip friction Phenomenon & الاحتكاك الارتجاجي & Gloss Translation \\
\hline Bioethics & الاخلاقيات الحيوية & Gloss Translation \\
\hline Genome-wide association & الارتباط على نطاق الجينوم & Gloss Translation \\
\hline Spatial resolution & الاستبانة الحَيُزيَّة & Gloss Translation \\
\hline Atomic resolution & الاستبانة الذرية & Gloss Translation \\
\hline Biosustainability & الاستدامة البيولوجية ـ النظم البيولوجية المستدامة & Transliteration \& Gloss Translation \\
\hline Spatiotemporally chaotic flows & التدفق الفوضوي زمانبّا ومكانبًاً & Gloss Translation \\
\hline Cellular recycling & التذوير الخلوي & Gloss Translation \\
\hline Computed microtomography & 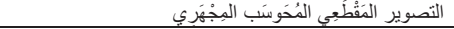 & Gloss Translation \\
\hline Confocal imaging & التصوير متشارك البؤرة & Gloss Translation \\
\hline Inflationary Universe & التضخم الكوني & Gloss Translation \\
\hline Recursive splicing & التضفير المتكرر & Gloss Translation \\
\hline Magnetostriction & التضييق المغناطبيسي & Gloss Translation \\
\hline Structural genomics & الجينو ميّات البنيويَّة & Gloss Translation \\
\hline Agroforestry & الحر اجة الزراعبة & Gloss Translation \\
\hline Pharmacokinetics & الحركية الدو ائية & Gloss Translation \\
\hline Cenozoic Era & الحقبة المعاصرة & Gloss Translation \\
\hline Competing endogenous RNAs & الحمض النووي الريبي الفطري المتنافِس & Gloss Translation \\
\hline microRNA & الحمض النووي الريبي متناهي الصغر & Gloss Translation \\
\hline Gluconeogenic genes & جينات تخليق السكر & Transliteration \& Gloss Translation \\
\hline Incidentalome & جينوم المصادفة & Transliteration \& Gloss Translation \\
\hline Biome & جينو مجمو عة كائنات حية & Transliteration \& Gloss Translation \\
\hline Endosome & 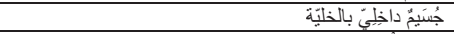 & Gloss Translation \\
\hline Inclusion body & 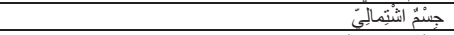 & Gloss Translation \\
\hline Oscillating electronic spin state & حالة دوران إلكتروني متذبذب & Gloss Translation \\
\hline Genome-wide information studies (GWAS) & ) ادراسات معلومات الجينوم (جواس & Transliteration \& Gloss Translation \\
\hline
\end{tabular}


ISSN 2039-2117 (online)

ISSN 2039-9340 (print)
Mediterranean Journal of Social Sciences MCSER Publishing, Rome-Italy
Vol 8 No 2

March 2017 